\title{
Working Fluid Selection for a Simple System of Low- Temperature Organic Rankine Cycle Plant
}

\author{
Budi Ismoyo ${ }^{1}$ M. Idrus Alhamid ${ }^{1, *}$ Muswar Muslim² \\ ${ }^{1}$ Mechanical Engineering Department University of Indonesia Depok, Indonesia \\ ${ }^{2}$ Marine System Engineering Department University of Darma Persada, DKI Jakarta, Indonesia \\ *Corresponding author. Email: mamak@eng.ui.ac.id
}

\begin{abstract}
Heat sources such as geothermal brine, biomass, and other waste heat sources have the potential to be recovered. Organic Rankine Cycle (ORC) plants can use to convert low-temperature heat sources into electrical energy. Working fluid selection for a simple system of the Organic Rankine Cycle plant is essential because the system works in limited conditions. This research will analyze the performance of several fluids that can use as working fluids. Simulation using EES, the selected fluid must have excellent cycle efficiency, a high volumetric vapor flow rate, and a high expansion pressure difference. Working fluids compared at a constant pump flow rate of 4.5 liters/minute with a heat source temperature range of $70-180{ }^{\circ} \mathrm{C}$ to obtain thermal efficiency, volumetric vapor flow rate, and expansion pressure difference of the expander. The simulation results obtained 11 types of work fluids that meet these criteria. Considering environmental aspects, three types of working fluids are ideal for testing. N-Pentane as a working fluid with the highest volumetric vapor flow rate. R-123 as a working fluid with the highest cycle efficiency. R-1233zd as a working fluid with the highest expansion pressure difference.
\end{abstract}

Keywords: Organic Rankine Cycle, working fluid, scroll expander, geothermal.

\section{INTRODUCTION}

Organic Rankine Cycle (ORC) plant-based operating systems have been commercially researched and developed over the past two decades. The application of ORC technology is very suitable for renewable heat sources such as geothermal, solar thermal, biomass, the heat of industrial waste residues, heat energy from exhaust engine, and ocean heat gradients. The Rankine cycle-based power system can be used as a joint generating system with the Combined Heat and Power (CHP) system and Waste Heat Recovery (WHR) system the relatively easy and reliable because of the application of the ORC system as a separate system. During the last three decades (1970-2000) exploration of geothermal energy resources in Indonesia has continued. This exploration has used the latest technology and methodology. Geothermal energy in Indonesia has moderate temperatures between $120-220{ }^{\circ} \mathrm{C}$ and high temperatures between $220-340{ }^{\circ} \mathrm{C}$ [1]. The brine heat source from the Geothermal Power Plant is relatively constant (mass flow, pressure, and temperature) because the existing geothermal wells generally consist of two phases, saturated liquid and saturated steam with relatively fixed percentages. Under these conditions, ORC technology is designed in a particular process so that the most efficient energy conversion can be obtained.

Many investigations about the application of ORC, for geothermal utilization, as in[2], evaluate cycle performance when evaporation and condensation temperatures, geothermal speed, and cooling water speed are varied - compared to the results obtained using ammonia, R123, n-pentane, and PF5050 as working fluids. Second, for solar energy utilization, as in[3], estimated the optimal operating conditions for ORC by comparing R123 and water as working fluids. The final category considered is a low-grade waste heat recovery, as in[4] analyzed the ORC efficiency using benzene, ammonia, R11, R12, R134a, and R113 as working fluids and analyzed system performance and optimized the working conditions of an ORC using R245fa[5].

In this study, a simple ORC plant uses a scroll expander to convert heat energy into electrical energy. This research is a preliminary study to obtain the right type of working fluid for the existing generating system compared to the working fluid currently being tested, R134a. Selected working fluids are work fluids that have 
high thermal efficiency, have a high expansion pressure difference and volumetric vapor flow rate meets with scroll expander specification and environmental aspects.

\section{MATERIALS AND METHODS}

\subsection{System Description}

The Rankine cycle is a basic cycle of steam power plants where the working fluid is evaporated and condensed continuously. The choice of working fluid is very dependent on the temperature range of the available heat source. Fig. 1 shows a simple organic Rankine cycle and fig. 2 an ideal temperature-entropy (T-s) diagrams of this cycle. The Rankine cycle operates in the following steps[6]:

(a) 1-2 Pump (Isentropic): Compression of the working fluid to high pressure using a pump.

(b) 2-3 Boiler/Evaporator (Isobaric): The compressed working fluid is heated to the final temperature (which is at boiling point) so that the liquid phase changes to vapor.

(c) 3-4 Turbine/Expander (Isentropic): Expansion of the vapor in the turbine/expander.

(d) 4-1 Condenser (Isobaric): Condensation of the vapor in the condenser where the waste heat goes to the final heat transfer to the atmosphere or a large body of water (ex. lake or river).

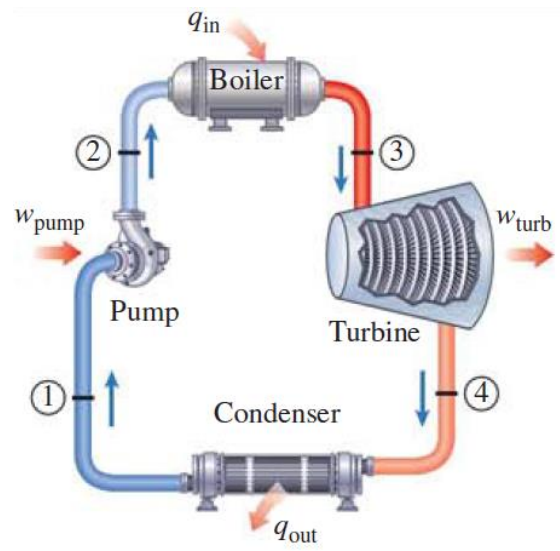

Figure 1 A simple system of Organic Rankine Cycle

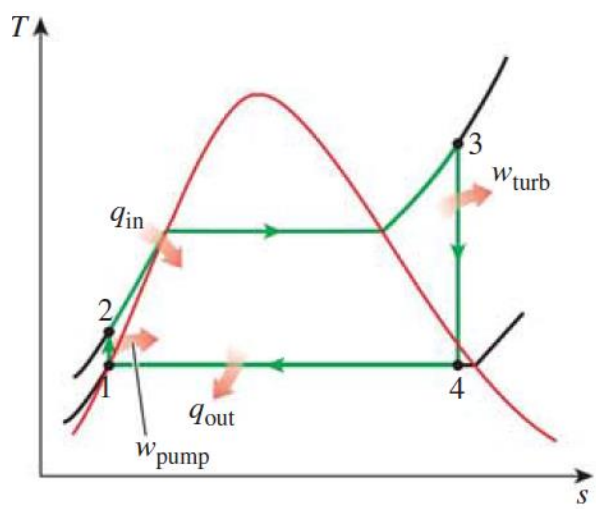

Figure 2 An ideal temperature-entropy (T-s) diagrams

\subsection{Thermodynamics Model}

Using the Engineering Equation Solver (EES) software, the mass and heat balance model of the ORC type above stated by the equation below. Work consumed by pumps $(W p)$ :

$$
\begin{aligned}
& W_{P}=\dot{m}_{w f}\left(h_{2}-h_{1}\right) \\
& \eta_{\text {is_pump }}=\left(h_{2 s}-h_{1}\right) /\left(h_{2}-h_{1}\right)
\end{aligned}
$$

where, $\dot{m}_{w f}$ is the mass flow rate of the working fluid in $\mathrm{kg} / \mathrm{s}, h_{1}, h_{2 s}, h_{2}$ represents the enthalpy values for process point $1,2 \mathrm{~s}$, and 2 in $\mathrm{kJ} / \mathrm{kg}$. $\eta_{\text {is_pump }}$ is the isentropic efficiency of the pump in \%.

Heat balance in the evaporator $\left(Q_{E V A P}\right)$ is listed in the equation below :

$$
Q_{E V A P}=\dot{m}_{w f}\left(h_{3}-h_{2}\right)
$$

where $h_{3}$ represent the enthalpy values for process point 3 , inlet expander in $\mathrm{kJ} / \mathrm{kg}$.

The work produced by the expander $\left(W_{T}\right)$ is listed in the equation below:

$$
\begin{aligned}
& W_{T}=\dot{m}_{w f}\left(h_{3}-h_{4}\right) \\
& \eta_{i_{-} \text {expander }}=\left(h_{3}-h_{4}\right) /\left(h_{3}-h_{4 s}\right)
\end{aligned}
$$

where $h_{4}, h_{4 s}$ represents the enthalpy values for process point 4 and $4 \mathrm{~s}$, outlet expander in $\mathrm{kJ} / \mathrm{kg}, \eta_{\text {is_expander }}$ is the isentropic efficiency of the expander in \%. The actual enthalpy after the compression and expansion steps determined from $\eta_{\text {is_expander }}$ and $\eta_{\text {is_pump }}$ values in the isentropic processes.

Heat balance in the condenser $\left(Q_{C O N D}\right)$ is listed in the equation below :

$$
Q_{\text {COND }}=\dot{m}_{w f}\left(h_{4}-h_{1}\right)
$$

where $h_{l}$ represent the enthalpy values for process point 1 , suction pump in $\mathrm{kJ} / \mathrm{kg}$.

The thermal efficiency of the cycle is listed in the equation below :

$$
\eta_{\text {cycle }}=\left(W_{T}-W_{P}\right) / Q_{E V A P}
$$

Expander specification must be meet with pump flow rate, which volumetric flow rate of vapor match with pump flow rate specification at 1500 RPM (25 RPS) speed rotation of scroll expander. 
$\dot{V}_{3}=\left(\dot{m}_{w f} / \rho_{3}\right) x 10^{6}$

$\frac{c m 3}{R E V}=\dot{V}_{3} \times 60 / R P M$

where $\dot{V}_{3}$ represent the volumetric vapor flow rate at point 3 in centimeter cubic/s $(\mathrm{cm} 3 / \mathrm{s}) . \mathrm{cm} 3 / \mathrm{rev}$ represent volumetric vapor needed by scroll expander per revolution.

$$
\text { Expansion Pressure Difference }=P_{3}-P_{4}
$$

where $P_{3}, P_{4}$ represents pressure at inlet expander point 3 and pressure at outlet expander point 4 in bar.

\subsection{Boundary Condition}

Starting the simulation use EES, estimation data is needed to make a simple calculation. Here are some input parameters needed for simulation :

1. The critical temperature of working fluids substance over $150{ }^{\circ} \mathrm{C}[7]$.

2. Source temperature range up to $165^{\circ} \mathrm{C}[8]$.

3. The terminal temperature difference of evaporator $15{ }^{\circ} \mathrm{C}$ and superheated temperature $5{ }^{\circ} \mathrm{C}$ to make sure all fluid became vapor.

4. Ambient temperature $35^{\circ} \mathrm{C}$ for city landfill[9].

5. Saturated temperature condenser $16{ }^{\circ} \mathrm{C}$ higher than ambient temperature[8] and subcool temperature 5 ${ }^{\circ} \mathrm{C}$ to make sure all fluid became liquid.

6. Pressure saturation at condenser higher than ambient pressure, not at vacuum pressure and no exceed 5 bar.

7. $\eta_{\text {is_expander }}=0.85 ; \eta_{\text {is_pump }}=0.65[10]$.

8. Pressure drop and heat losses from the components and pipelines are neglected[11].

9. Test bench: pump flow rate up to 4.5 liters/minute.

\subsection{Methodology}

Methodology in this study following flowchart below

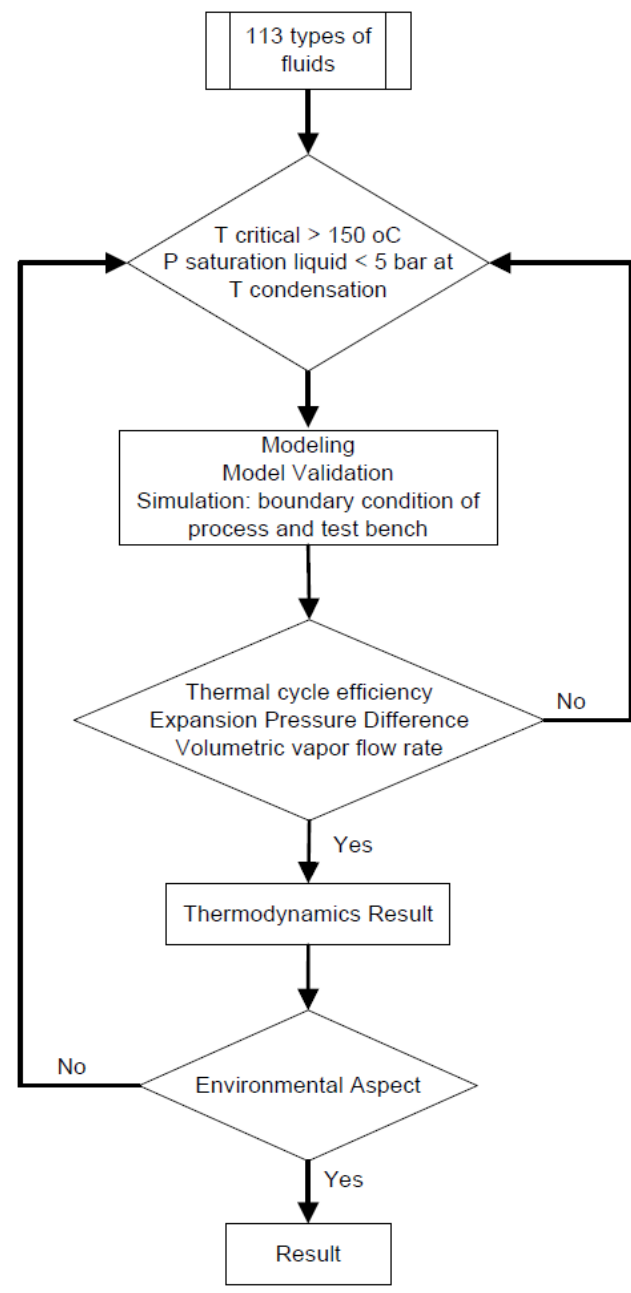

Figure 3 Flowchart of methodology

\section{RESULT}

\subsection{Model Validation}

A comparative study in our previous literature[12] between the present work gives the results in good agreement with this literature. See in the table 1.

\subsection{Parametric Study}

The modeling results obtained 11 types of liquids that have the potential to be used as working fluids. The results of work fluid modeling seen based on environmental issues, safety, and thermodynamic processes can see in table 2 .

\section{CONCLUSION}

Five types of working fluids, referring to environmental issues, substances with lower ODP and GWP are ideal to be used as ORC plant work fluids. There are isopentane, n-pentane, neopentane, R123, and R1233zd. While referring to the thermodynamic aspects, parameters of cycle efficiency, volumetric vapor flow rate, and expander expansion pressure difference can be selected as parameters to evaluate the performance of the 
ORC plant system. Then of the five types of working fluids, R123 as the working fluid with the highest thermal cycle efficiency $13.43 \%$, n-pentane as the working fluid with the highest volumetric vapor flow rate 43.52 $\mathrm{cm}^{3} /$ revolution, and R1233zd as the working fluid with the highest expansion pressure difference 21.57 bar. Those are the working fluids that ideal to be tested and compared.

Table 1. Show a comparative study in our previous literature between present work give the results in good agreement with these literature

\begin{tabular}{|lcccr|}
\hline Performance Parameter & Unit & Present Work & Safarian,S et al[12] & Relative Error \% \\
\hline Working Fluid & & R113 & R113 & - \\
\hline Evaporator Duty & $\mathrm{kW}$ & 252 & 252 & $0.198 \%$ \\
Condensor Duty & $\mathrm{kW}$ & 202.4 & 202 & $1.157 \%$ \\
Turbine Power & $\mathrm{kW}$ & 51.59 & 51 & $1.173 \%$ \\
Pump Power & $\mathrm{kW}$ & 1.937 & 1.96 & $1.233 \%$ \\
Thermal Efficiency & $\%$ & 19.7 & 19.46 & $0.943 \%$ \\
Mass flow (organic fluid) & $\mathrm{kg} / \mathrm{s}$ & 1.05 & 1.06 & \\
\hline
\end{tabular}

Table 2. Environmental issues, safety and thermodynamic processes of working fluids at saturated vapor temperature $145^{\circ} \mathrm{C}$ (Superheat temperature $5{ }^{\circ} \mathrm{C}$ )

\begin{tabular}{|c|c|c|c|c|c|c|}
\hline Fluids & $\begin{array}{l}\text { Ozone Depletion } \\
\text { Potential (ODP) }\end{array}$ & $\begin{array}{l}\text { Global } \\
\text { Warming } \\
\text { Potential } \\
\text { (GWP) }\end{array}$ & $\begin{array}{l}\text { ASHRAE } \\
\text { Standard } 34^{[16]}\end{array}$ & $\begin{array}{l}\text { Cycle } \\
\text { Efficiency (\%) }\end{array}$ & $\begin{array}{l}\text { Volumetric Vapor } \\
(\mathrm{cm} 3 / \mathrm{rev})\end{array}$ & $\begin{array}{l}\mathrm{P}_{3}-\mathrm{P}_{4} \\
\text { (bar) }\end{array}$ \\
\hline Isopentane & $0^{[13]}$ & $25^{[13]}$ & $\mathrm{A} 3$ & 12.61 & 34.76 & 14.69 \\
\hline $\mathrm{n}$-pentane & $0^{[13]}$ & $25^{[13]}$ & A3 & 12.91 & 43.52 & 12.64 \\
\hline Neopentane & $0^{[13]}$ & $25^{[13]}$ & A3 & 11.61 & 18.98 & 20.75 \\
\hline R11 & $1^{[13]}$ & $4000^{[13]}$ & A1 & 13.99 & 40.8 & 16.58 \\
\hline R113 & $0.8^{[14]}$ & $6130^{[14]}$ & A1 & 13.5 & 59.51 & 9.813 \\
\hline R123 & $0.02^{[15]}$ & $77^{[15]}$ & B1 & 13.43 & 34.43 & 16.71 \\
\hline R141b & $0.11^{[13]}$ & $713^{[13]}$ & A2 & 13.73 & 48.13 & 14.23 \\
\hline R245fa & $0^{[15]}$ & $1030^{[15]}$ & B1 & 12.16 & 18.11 & 26.73 \\
\hline R365mfc & $0^{[13]}$ & $782^{[13]}$ & & 12.63 & 39.56 & 13.67 \\
\hline R1233zd & $0^{[15]}$ & $1^{[15]}$ & A1 & 12.79 & 23.6 & 21.57 \\
\hline SES36 & & & & 12.32 & 31 & 14.11 \\
\hline
\end{tabular}




\section{REFERENCES}

[1] Nasruddin, Idrus Alhamid M, Daud Y, Surachman A, Sugiyono A, Aditya H B, Mahlia I. "Potential of geothermal energy for electricity generation in Indonesia: A review." Renewable and Sustainable Energy Reviews, 53, 2016: 733-740

[2] Madhawa HD, Golubovic M, Worek WM, Ikegami Y. "Optimum design criteria for an Organic Rankine cycle using low-temperature geothermal heat sources." Energy, 32(9), 2007: 1698-1706.

[3] Yamamoto T, Furuhata T, Arai N, Mori K. "Design and testing of the Organic Rankine Cycle." Energy, 26(3), 2001: 239-251

[4] Hung TC, Shai TY, Wang SK. "A review of organic rankine cycles (ORCs) for the recovery of lowgrade waste heat." Energy, 22(7), 1997: 661-667

[5] Wei D, Lu X, Lu Z, Gu J. "Performance analysis and optimization of organic Rankine cycle (ORC) for waste heat recovery." Energy Conversion and Management, 48(4), 2007: 1113-1119

[6] Yunus A. Cengel, Michael A. Boles. Thermodynamics: An Engineering Approach. Ninth Edition. New York: McGraw-Hill Education; 2019

[7] Marin A, Dobrovicescu A, Grosu L, Adina. "Energy and Exergy Analysis of An Organic Rankine Cycle." 2014

[8] Bambang Teguh P, Himawan S, Suyanto, Taufan S, Agustina L, Yasser R, et al. "Design and Testing of n-Pentane Turbine for $2 \mathrm{~kW}$ Model of Binary Cycle Power Plant." Proceedings World Geothermal Congress. Bali-Indonesia, 2010

[9] BMKG. Cuaca Ekstrim Stasiun Meteorologi Kemayoran. 2019. http://dataonline.bmkg.go.id/

[10] Saleh B, Koglbauer G, Wendland M, Fischer J. "Working fluids for low-temperature organic Rankine cycles." Energy, 32(7), 2007: 1210-1221

[11] Parikhani T, Gholizadeh T, Ghaebi H, Sattari Sadat SM, Sarabi M. "Exergoeconomic optimization of a novel multigeneration system driven by geothermal heat source and liquefied natural gas cold energy recovery." Journal of Cleaner Production, 209, 2019: 550-571

[12] Safarian S, Aramoun F. "Energy and exergy assessments of modified Organic Rankine Cycles (ORCs)." Energy Reports, 1, 2015: 1-7

[13] UNEP. "Montreal Protocol On Substances That Deplete The Ozone Layer." 2016
[15] Honeywell Refrigerant. www.honeywellrefrigerants.com

[16] ANSI/ASHRAE Standard 34. "Designation and Safety Classification of Refrigerants."

[14] Ozone Depleting Substances. https://www.epa.gov/ 